\title{
Os Impactos da Declaração Universal dos Direitos Humanos Sobre o Desenvolvimento do Novo Direito Internacional
}

\author{
Sidney Cesar Silva Guerra \\ Pós-doutor pelo Centro de Estudos Sociais da Universidade de Coimbra e pelo Programa Avançado em Cultura Contemporânea da \\ Universidade Federal do Rio de Janeiro (UFRJ). Doutor e mestre em Direito (UGF). Professor do Programa de Pós-Graduação em \\ Direito Internacional (Doutorado e Mestrado) na Universidade do Estado do Rio de Janeiro (UERJ). Professor-associado da Univer- \\ sidade Federal do Rio de Janeiro (UFRJ). Professor titular da Universidade do Grande Rio (Unigranrio). Líder do Grupo de Pesquisa \\ em Direito Internacional (GPDI/FND/UFRJ). Advogado. http://lattes.cnpq.br/6208018085527826. http://orcid.org/0000-0002-5309- \\ 662X. sidneyguerra@terra.com.br

\section{Fernanda Figueira Tonetto} \\ Doutora em Direito pela Université Paris II Panthéon-Assas - France. Doutora e mestre em Direito Internacional pela Universidade \\ Federal do Rio Grande do Sul - Brasil. Mestre em Integração Latino-Americana pela Universidade Federal de Santa Maria - Brasil. \\ Procuradora do Estado do Rio Grande do Sul nos Tribunais Superiores - Brasília. http://lattes.cnpq.br/3749612744684700. \\ fernandafigueiratonetto@gmail.com
}

Ainda que o Direito Internacional tenha origens que remontem ao antigo Direito das Gentes, pode-se dizer que sua faceta moderna, que coloca o indivíduo no centro do seu espectro de proteção, nasce em período posterior. Se as primeiras raízes do novo Direito Internacional começam a nascer no fim do século 19 , com o surgimento do Direito Internacional Humanitário, é possível afirmar, de outro lado, que o segundo pós-guerra se constitui em um marco para novos paradigmas do Direito Internacional. Esse é o momento histórico em que se inaugura o sistema de proteção das Nações Unidas e toda uma construção normativa iniciada com a Declaração Universal dos Direitos Humanos, do qual emerge toda uma constituição jurisprudencial oriunda das Cortes Internacionais e Regionais. Diante de todo esse contexto, o presente trabalho tem por objetivo analisar os impactos trazidos pela Declaração Universal dos Direitos Humanos na estruturação do Direito Internacional moderno, cotejando-a com o desenvolvimento do Direito Internacional dos direitos humanos, do qual pode-se extrair quais os valores mais caros pertencentes à comunidade humana em seu conjunto. Para atingir o objetivo proposto serão utilizados o método histórico de procedimento, por meio de uma análise evolutiva dessas construções. Será empregado igualmente o método hipotético-dedutivo de abordagem, o qual parte da hipótese de que a humanidade possui valores absolutos e universais a serem protegidos por esse sistema.

Palavras-chave: Novo Direito Internacional. Declaração Universal dos Direitos Humanos. Valores universais da humanidade. Direito Internacional humanitário. Direito Internacional dos direitos humanos.

\section{THE IMPACTS OF THE UNIVERSAL DECLARATION OF HUMAN RIGHTS ON THE} DEVELOPMENT OF NEW INTERNATIONAL LAW

\section{ABSTRACT}

Although international law has origins that go back to the old law of the people, it can be said that its modern facet, which places the individual at the center of its protection spectrum, is born in a later period. If the first roots of the new international law begin to emerge at the end of the 19th century, with the emergence of international humanitarian law, it can be stated, on the other hand, that the second post-war is a milestone for new paradigms of international law. This is the historical moment in which the United Nations protection system is inaugurated and a normative construction initiated with the Universal Declaration of Human Rights, from which emerges a whole jurisprudential construction coming from the International and Regional Courts. In this context, the following research aims to analyze the system of protection of human rights inaugurated by the creation of the United Nations and the Universal Declaration of Human Rights, as well as to extract from it the most important values belonging to the human community as a whole. To reach the proposed objective, the historical procedure method will be used, by an evolutionary analysis of conventional constructions and jurisprudential. The hypothetical-deductive method of approach will also be used, which is based on the hypothesis that humankind has absolute and universal values to be protected by this system.

Keywords: New international law. Universal Declaration of Human Rights. Universal values of humanity. International humanitarian law. International human rights law.

1 Introdução. 2 O Novo Direito Internacional e a Identificação dos Valores Humanos Universais Fundados pela DUDH. 3 Um Novo Direito Internacional? 4 Considerações Finais. 5 Referências. 


\section{Humanos e \\ Democracia}

\section{INTRODUÇÃO}

Do contexto histórico do fim do século 18 , do qual emergem os projetos de paz perpétua, ${ }^{1}$ se unem movimentos do século seguinte inspiradores do (re)nascimento de um Direito das Gentes erigido sobre bases que têm os indivíduos e os elos por eles formados no centro de sua proteção, os quais ganharão ainda maior força com a chegada do Direito Internacional humanitário.

Ainda que o Direito Internacional tenha origens que remontem ao antigo Direito das Gentes, pode-se argumentar que sua faceta moderna, que coloca o indivíduo no centro do seu espectro de proteção, nasce posteriormente a esse contexto. Se as primeiras raízes do novo Direito Internacional começam a nascer no fim do século 19 , com o surgimento do Direito Internacional humanitário, pode-se afirmar, de outro lado, que o segundo pós-guerra se constitui em um marco para novos paradigmas do Direito Internacional. Esse é o momento histórico em que se inaugura o sistema de proteção das Nações Unidas e toda uma construção normativa iniciada com a Declaração Universal dos Direitos Humanos.

A Declaração Universal dos Direitos Humanos e, com ela, a criação de todo o aparato de proteção fundado pelo sistema das Nações Unidas são dois pilares do segundo pós-guerra que dão nascimento a um novo Direito Internacional, ${ }^{2}$ que passa a ter como braços principais o Direito Internacional dos direitos humanos ${ }^{3}$ e o Direito Internacional Penal.

Esse novo sistema começa a se desenvolver a partir da adoção de uma série de convenções internacionais, de modo a inaugurar uma espécie de sociedade humana universal ${ }^{4}$ (oposta ao modelo arcaico dos Estados soberanos) que, como tal, funda-se no respeito pelo ser humano.

A doutrina do Direito Internacional e, especialmente, do Direito Internacional dos direitos humanos, passa a se relacionar com outros campos do Direito e embasa aspectos, por exemplo, do Direito Internacional Penal que se relacionam à defesa de uma ordem de sociedade humana universal e lhe impregnam conteúdo. Essa noção aplica-se perfeitamente à edificação do conceito de crime contra a humanidade e do crime de genocídio, porquanto se tratam de crimes que afetam o que há de humano em todos os seres humanos sem exceção

\footnotetext{
1 Essas ideias possuem suas primeiras sementes no pensamento de Abbée de Saint-Pierre, passando por Claude-Henri de Saint-Simon e tendo como grande estandarte a obra de Immanuel Kant.

2 Como afirma Thomas Buergenthal, "traditional international law developed various doctrines and institutions that were designed to protect different groups of human beings: slaves, minorities, certain native populations, foreign nationals, victims of very massive violations, combatants, etc. That law and practice provided the conceptual and institutional underpinnings of contemporary international human rights law. The most important feature of that law is that it recognizes that individuals have rights as human beings and that these rights are protected by international law". In: BUERGENTHAL, Thomas. International Human Rights. St. Paul: West Publishing Co., 1988, p. 16.

3 Vide a propósito GUERRA, Sidney. Direito internacional dos direitos humanos. 2. ed. São Paulo: Saraiva, 2015.

4 "[...] il y a une autre dimension des droits de l'Homme qui correspond à une définition fonctionnelle : ceux-ci sont aussi l'expression la plus directe du modèle de la Société humaine universelle, face au modèle de la Société des Etats souverains. "L'introduction des droits de l'Homme dans l'ordre juridique international signifie en effet que le droit international, comme le droit interne, devrait être fondé sur le respect de la liberté et de la dignité de l'être humain. Cela signifie aussi que le seul vrai sujet de droit est l'individu". FROUVILLE, Olivier de. Droit international pénal. Sources. Incriminations. Responsabilité. Paris: Pédone, 2012. p. 8.
} 
- o irredutível humano ${ }^{5}$ - e essa definição comum de humanidade é precisamente o que o Direito Internacional dos direitos humanos se desincumbe mais facilmente de identificar. Ele o faz tanto por meio das convenções internacionais de direitos humanos quanto pelas decisões oriundas das jurisdições internacionais que as aplicam, auxiliando na tarefa de identificar os valores universais, os denominados valores intangíveis da humanidade.

Nesse sentido, esse novo Direito Internacional passa a edificar uma série de valores, tendo na construção normativa fundada pela Declaração Universal dos Direitos Humanos uma pedra fundamental que permite a identificação de valores humanos a promover sem qualquer espécie de relativização

Essa identificação se deu tanto por força do Direito Internacional convencional dos direitos humanos quanto pela construção da jurisprudencial.

\section{O NOVO DIREITO INTERNACIONAL E A IDENTIFICAÇÃO DOS VALORES HUMANOS UNIVERSAIS FUNDADOS PELA DUDH}

Uma nova configuração do Direito Internacional, que permitirá a identificação dos valores fundamentais da humanidade, ganha uma significativa riqueza de contornos a partir da grande produção de convenções internacionais de direitos humanos que começa a ocorrer especialmente após o segundo pós-guerra, impulsionada pela Declaração Universal dos Direitos Humanos, pela criação das Nações Unidas e pelo surgimento dos sistemas regionais de proteção de direitos humanos.

A criação das Nações Unidas inaugura o que se pode chamar sistema universal de proteção e, desde o seu primeiro alicerce, esse edifício traz expresso o que entende por valor essencial a proteger: o preâmbulo da Carta de São Francisco contém em suas linhas iniciais uma declaração de fé nos direitos fundamentais do homem e na dignidade e no valor do ser humano, ${ }^{6}$ aparentemente erigindo a dignidade humana como base subjacente desses direitos fundamentais.

O valor dignidade humana será, a partir de então, acredita-se, a pedra de toque da construção normativa subsequente. Pormenorizando o conteúdo da Declaração Universal dos Direitos Humanos, o Pacto Internacional de Direitos Civis e Políticos ${ }^{7}$ e o Pacto Internacional de Direitos Econômicos, Sociais e Culturais reconhecem em seu preâmbulo a dignidade inerente a todos os membros da família humana e de seus direitos iguais e inalienáveis, entendendo que esta dignidade constitui o fundamento da liberdade, da justiça e da paz no mundo.

\footnotetext{
A ideia do irredutível humano consiste justamente na tentativa de isolar um núcleo duro de direitos dos seres humanos, os quais não podem lhes ser negados (irredutíveis) e que são, portanto, irrevogáveis, independentemente do tempo atemporais (do que decorre a imprescritibilidade do crime contra a humanidade) - e do espaço (do que decorre a sua universalidade). Sobre a noção de irredutível humano, ver: DELMAS-MARTY, Mireille. Le crime contre l'humanité, les droits de l'homme et l'irréductible humain. Revue de science criminelle et de droit pénal comparé, Paris, n. 3, Jui-Sep. 1994, p. 477-490.

6 Preâmbulo da Carta das Nações Unidas, São Francisco, 26 de junho de 1945.

7 Preâmbulo do Pacto Internacional de Direitos Civis e Políticos de 16 de dezembro de 1966 e do Pacto Internacional de Direitos Econômicos, Sociais e Culturais de 19 de dezembro de 1966.
} 


\section{Humanos e \\ Democracia}

O primeiro instrumento, ampliando o rol de direitos civis e políticos contidos na Declaração, além de criar para os Estados a obrigação positiva de respeitá-los e promovê-los, enumera direitos que não são passíveis de sofrer essas restrições, o que aponta para alguns indícios acerca de quais desses direitos possuem a conotação de prerrogativas absolutas, uma vez que não podem ser relativizados no plano do Direito interno.

Trata-se dos direitos previstos no Pacto em seus artigos 60 (direito à vida), 70 (interdição da tortura e de tratamentos cruéis, degradantes ou desumanos), 8 (interdição da escravidão), 11 (interdição da prisão por descumprimento de obrigação contratual), 15 (proibição de ser processado por fato que não seja previsto como crime ou que não seja considerado delituoso de acordo com os princípios reconhecidos pela comunidade das nações), 16 (direito ao reconhecimento da personalidade jurídica a todas as pessoas) e 18 (direito à liberdade de pensamento, de consciência e de religião), conforme previsão restritiva de seu artigo 4ㅇ. ${ }^{8}$

A impossibilidade de relativização desses direitos parece estar ligada ao valor subjacente a eles. Quando o preâmbulo afirma que a dignidade humana constitui o fundamento da liberdade, da justiça e da paz, pensa-se que é esse valor dignidade que se encontra inerente à impossibilidade de que os direitos a ela intimamente ligados sejam excepcionados.

Apesar de não criar obrigações imediatas de cumprimento aos Estados, de uma maneira mais sutil, mas com o mesmo objetivo de fazer respeitar esses direitos, o Pacto Internacional de Direitos Econômicos, Sociais e Culturais determina aos Estados o compromisso de adotar medidas para satisfazê-los, devendo fazê-lo de forma progressiva, inclusive mediante a adoção de disposições legislativas.

O substrato da dignidade humana como fundamento de direitos universais e absolutos continua a servir como catalisador da construção normativa subsequente à criação das Nações Unidas e em textos como a Declaração Universal dos Direitos Humanos de 1948.

Embora a Declaração não possua valor de tratado internacional, ${ }^{9}$ entende-se que seu teor se constitui em uma tentativa de expressar os valores principais da comunidade humana, trazendo um corpo de princípios e de prerrogativas individuais e coletivas que o alçam à categoria de Direito Internacional consuetudinário.

Simbolizando alguns dos valores mais caros da sociedade contemporaneamente à sua proclamação, como um modelo acerca do que a comunidade internacional e a consciência jurídica universal entendem por direitos mais fundamentais, a Declaração Universal dos Direi-

\footnotetext{
Pacto Internacional sobre Direitos Civis e Políticos. Artigo 4‥ 1. Quando situações excepcionais ameacem a existência da nação e sejam proclamadas oficialmente, os Estados Partes do presente Pacto podem adotar, na estrita medida exigida pela situação, medidas que suspendam as obrigações decorrentes do presente Pacto, desde que tais medidas não sejam incompativeis com as demais obrigações que lhes sejam impostas pelo Direito Internacional e não acarretem discriminação alguma apenas por motivo de raça, cor, sexo, língua, religião ou origem social. 2. A disposição precedente não autoriza qualquer suspensão dos artigos 60, 7ㅇ, 8 (parágrafos 1 e 2) 11, 15, 16 e 18.

9 “En la práctica de las Naciones Unidas, una declaración es un instrumento solemne, que se utiliza sólo en casos muy especiales, en cuestiones de grande y verdadera importancia y cuando se espera obtener el máximo de observancia por parte del mayor número de Estados posible. Así pues, son las declaraciones actos solemnes por las cuales representantes gubernamentales proclaman su adhesión y apoyo a principios generales que se juzgan como de gran valor y perdurabilidad, pero que no son adaptados con la formalidad ni con la fuerza vinculante de los tratados". VENTURA-ROBLES, Manuel E. El valor de la Declaración Universal de Derechos Humanos. In: CANÇADO TRINDADE, Antonio Augusto (org.). The modern world of human rights - El mundo moderno de los derechos humanos: Essays in honour of Thomas Buergenthal. Ensayos en Honor de Thomas Buergenthal. San José: Instituto Interamericano de Derechos Humanos, 1996. p. 257-258.
} 
tos Humanos ganha força normativa ou valor jurídico na medida em que serve de parâmetro para medir o quanto os Estados promovem ou desrespeitam os direitos dos indivíduos que se encontram sob sua tutela.

Esses direitos são proclamados sob a forma de duas categorias: de um lado, os direitos civis e políticos e, de outro, os direitos econômicos, sociais e culturais.

Como parte dos primeiros encontram-se o direito à vida, à liberdade, à segurança pessoal, à liberdade de expressão, de religião, de associação e de locomoção, a não ser detido arbitrariamente, a proibição da escravidão, da tortura, de tratamentos cruéis, degradantes e desumanos, além de direitos processuais como o devido processo legal, a presunção de inocência, e de direitos políticos, como o de eleger representantes e ser elegível.

Como parte dos segundos estão o direito à assistência social, ao trabalho, a um nível de vida adequado, à educação e ao acesso à cultura

Existe, no entanto, uma diferença entre o fato de esses direitos serem universais, o que significa que são reconhecidos por todas as comunidades humanas, e o fato de serem absolutos, o que seria a impossibilidade de lhes impor limitações. A própria Declaração reconhece que muitos deles são relativos, e isso permite aos Estados, dentro de certos limites que não impliquem a sua supressão, impor-lhe igualmente regulações.

Tais direitos devem ser analisados em cotejo com as regras de jus cogens, permitindo-se perquirir em que hipóteses essas restrições não são possíveis a ponto de lhes atribuir o caráter de direitos universais e absolutos.

Mais uma vez, portanto, o valor dignidade deve servir como medida para se cotejar a natureza desses direitos, entendendo-os por direitos absolutos e universais quando a sua limitação se configurar em violação à dignidade humana. Essa análise parece ainda mais coerente se a violação de um desses direitos, em ofensa à dignidade humana, caracterizar um crime de genocídio ou um crime contra a humanidade, na medida em que esses crimes visam à proteção de direitos que não admitem limitação. É o caso, por exemplo, da impossibilidade da excepcionalização da tortura. A criação de exceções ao direito de todas as pessoas de não serem torturadas não integra a margem de apreciação nacional. A proibição da tortura é regra que pertence ao núcleo duro de direitos de jus cogens.

Esse mesmo tom que emerge da dignidade humana aparece na Convenção sobre a eliminação de todas as formas de discriminação racial de 1965. Ela positiva sob a forma de um tratado internacional a igualdade de todas as raças e cria um sistema jurídico norteado pelo princípio de não discriminação, de modo a proibir todo e qualquer ato de discriminação racial consistente na distinção, exclusão, restrição ou preferência adotados por razões de raça, cor, linhagem, origem nacional ou étnica. 


\section{Humanos e \\ Democracia}

O direito à não discriminação é igualmente consequência do postulado geral da dignidade de todos os seres humanos, proclamada nos textos anteriores, como a Carta das Nações Unidas e a Declaração Universal dos Direitos Humanos. ${ }^{10}$ Ele confirma a ideia de que a dignidade humana serve como valor subjacente à proteção de direitos que se compreende por universais e impassíveis de relativização.

O instrumento consiste em fonte de obrigações negativas e positivas aos Estados, na medida em que os obriga à prática da não discriminação por interposição de seus agentes e a adequar seus respectivos ordenamentos jurídicos de forma a torná-los compatíveis com o Direito Internacional. Tal aspecto parece demonstrar uma certa supremacia do Direito Internacional sobre o Direito Interno naquilo em que legitimamente protege um valor universal, porquanto impõe aos Estados a obrigação de realizar o controle de convencionalidade de seu Direito Interno e lhes retira uma parcela significativa da margem nacional de apreciação.

Encontra-se sob a égide do mesmo princípio a Convenção Internacional sobre a eliminação e a repressão do crime de apartheid de 1973, que o tipifica como um crime contra a humanidade. A Convenção os define como sendo as práticas e políticas de segregação racial ocorridas no sul da África e cria um sistema paralelo de responsabilização, da mesma forma como o faz a Convenção do genocídio. Nesse sentido, atribui responsabilidade tanto aos Estados quanto aos indivíduos, com previsão, quanto a esses, de competência universal.

Ao analisar outras convenções internacionais que possuem finalidades semelhantes, elaboradas em seguimento à criação das Nações Unidas, paralelamente ao valor dignidade humana transparece a emergência de um outro valor, de natureza negativa, que se relaciona com o sofrimento humano.

O propósito de proteção da dignidade humana, valor positivo a promover conjugado com o intuito de prevenir o sofrimento humano, valor negativo a interditar, será a pedra de toque da construção normativa orquestrada pelo sistema universal das Nações Unidas, composta não somente de convenções internacionais como também na praxe da organização consistente na elaboração de uma série de resoluções. ${ }^{11}$

A proteção desses valores parece estar clara, por exemplo, no texto da Convenção sobre a prevenção e a repressão do crime de genocídio de 1948, que teve como fator determinante as práticas de extermínio dos judeus e de minorias nacionais, étnicas e religiosas durante a Segunda Guerra Mundial e foi adotada a partir da construção criada por Raphaël Lemkin ${ }^{12}$ e em seguida pelos trabalhos impulsionados pela Resolução 96 (I) da Assembleia Geral de 11 de dezembro de 1946. A Resolução começou por explicitar o conceito de genocídio e o descre-

\footnotetext{
${ }^{10}$ SUDRE, Frédéric. Droit européen et international des droits de l'homme. 13. édition refondue. Paris: Presses universitaires de France, 2016. p. 427.

${ }^{11}$ CANÇADO TRINDADE, Antônio Augusto. Princípios do direito internacional contemporâneo. 2. ed. Brasília: Fundação Alexandre de Gusmão, 2017. p. 359.

12 Lemkin criou a palavra genocídio a partir da união do termo grego genos (raça) com o termo latino caedere (matar), que gera o sufixo cide. $\mathrm{O}$ jurista polonês criou o termo em resposta a Churchill quando se referia aos crimes sem nome cometidos pelos nazistas. Apesar de seu trabalho datar de 1944, durante o processo de Nuremberg, os acusados não tiveram seus atos qualificados como crimes de genocídio, mas sim como crimes contra a humanidade em conexão com crimes de guerra. Ainda assim, a expressão foi utilizada diversas vezes pela acusação, o que auxiliou na criação de uma consciência universal acerca da existência do crime de genocídio no Direito Internacional costumeiro e a sua posterior positivação pelas Nações Unidas. In: AXIS RULE IN OCCUPIED EUROPE. Carnegie Endowment for International Peace. Washington D.C., 1944.
} 
veu como sendo a recusa do direito à existência de grupos humanos inteiros, recusa essa que afeta a consciência humana, inflige grandes perdas à humanidade, a qual se encontra assim privada de aportes culturais ou outros aportes desses grupos e é contrária à lei moral, ao espírito e aos fins das Nações Unidas.

A Assembleia Geral classificou o genocídio como crime de Direito das Gentes que o mundo civilizado condena e pelo qual seus autores, quaisquer que sejam (pessoas privadas, funcionários ou homens de Estado), devem ser punidos e convidou igualmente os Estados-membros a adotarem medidas legislativas necessárias para prevenir e reprimir esse crime, para isso encarregando o Conselho Econômico e Social de fazer os estudos necessários para redigir o projeto de convenção.

Em seguida, a Resolução 260 (III), de 9 de dezembro de 1948, da Assembleia Geral da ONU, adotou o texto da Convenção e definiu o genocídio como sendo o ato cometido com a intenção de destruir, total ou parcialmente, um grupo nacional, étnico, racial ou religioso, por meio do homicídio de seus membros, ofensa grave à integridade física ou psíquica de integrantes do grupo, submissão a condições de existência capazes de levar à sua destruição física ou psíquica, impedimento de nascimentos no seio do grupo ou transferência forçada de crianças de um grupo para outro.

A Convenção impôs aos Estados uma obrigação no sentido de adotarem as medidas legislativas necessárias para assegurar a aplicação das disposições nela contidas e determinou que os Estados devem prever sanções eficazes contra os responsáveis por crime de genocídio, determinando expressamente que este não pode ser considerado crime político pelo Direito Nacional ${ }^{13}$ e não sujeito à imunidade. ${ }^{14}$

A Convenção prevê ainda duas espécies de jurisdição em decorrência da prática do crime de genocídio: possui competência a Corte Internacional de Justiça para a solução de conflitos entre Estados, compreendendo-se a responsabilização civil do Estado, bem como a interpretação, a aplicação e a execução da convenção;; ${ }^{15}$ para a responsabilização pessoal, o que significa responsabilidade penal; a Convenção prevê igualmente que os sujeitos serão responsabilizados diante dos tribunais competentes do território do Estado onde o ato foi cometido ou perante uma Corte criminal internacional. ${ }^{16}$

$\mathrm{Na}$ época em que foi redigido o texto da Convenção, não existia Tribunal Penal Internacional, pois as duas Cortes então criadas (Nuremberg e Tóquio) foram Tribunais ad hoc com competência para julgar os fatos ocorridos durante a Segunda Guerra Mundial. Por isso, seu final foi consagrado à previsão de um estudo pela Comissão de Direito Internacional a res-

\footnotetext{
${ }^{13}$ Artigo $7^{\circ}$ da Convenção para a prevenção e repressão do crime de genocídio, adotada pela Assembleia Geral das Nações Unidas em 9 de dezembro de 1948.

${ }^{14}$ Artigo $4^{\circ}$ da Convenção para a prevenção e repressão do crime de genocídio, adotada pela Assembleia Geral das Nações Unidas em 9 de dezembro de 1948.

${ }^{15}$ Artigo $9^{\circ}$ da Convenção para a prevenção e repressão do crime de genocídio, adotada pela Assembleia Geral das Nações Unidas em 9 de dezembro de 1948.

${ }^{16}$ Artigo $6^{\circ}$ da Convenção para a prevenção e repressão do crime de genocídio, adotada pela Assembleia Geral das Nações Unidas em 9 de dezembro de 1948.
} 


\section{Democracia}

Humanos e

peito da questão de uma jurisdição criminal internacional. De todo modo, o texto invoca a evolução da comunidade internacional e a necessidade cada vez mais crescente de um órgão judiciário internacional encarregado de julgar certos crimes do Direito das Gentes.

Inicialmente, cogitava-se que esta comissão de Direito Internacional, ao fazer este estudo, tomasse em consideração a possibilidade de criar uma câmara criminal na própria Corte Internacional de Justiça o que, sabe-se, foi um plano que restou entorpecido pela guerra fria, uma vez que um novo tribunal internacional só veio a ser instituído após os massacres na ex-lugoslávia e em Ruanda.

A proteção da dignidade humana e a interdição do sofrimento humano são igualmente subjacentes em convenções internacionais, como a Convenção contra a tortura e outras penas e tratamentos cruéis, desumanos ou degradantes, de 1984, e a Convenção das Nações Unidas para a proteção de todas as pessoas contra os desaparecimentos forçados, de $2006 .{ }^{17}$

A interdição da tortura, a partir dos termos da Convenção, assume um caráter de direito universal e absoluto na medida em que declara que não existe nenhuma circunstância, ainda que de extrema excepcionalidade, que possa justificar o seu cometimento. ${ }^{18}$

Em seu artigo 2을 a Convenção cria para os Estados a obrigação positiva de adotar medidas legislativas, administrativas e judiciais para impedir todas as espécies de atos de tortura em seus respectivos territórios, bem como a obrigação positiva de proteção e prevenção, ${ }^{19}$ criando para os Estados, além disso, uma obrigação negativa específica consistente em assegurar a proibição da prática de tortura, cujo monitoramento fica a cargo de um sistema de supervisão composto da exigência de apresentação de informações pelos Estados, pela utilização de reclamações e por meio de petições individuais. ${ }^{20}$

\footnotetext{
${ }^{17}$ Não se incluiu aqui a Convenção sobre a proibição de trabalhos forçados de 1957, tendo em vista que embora a interdição de trabalhos forçados seja reconhecida como proibição, ganhando caráter de proibição absoluta quando se trata de escravidão, essa interdição já teve sua relativização sedimentada na jurisprudência quando se trata, por exemplo, de trabalho de detentos, de serviço militar ou de trabalho em caso de força maior, os quais seriam resultantes de obrigações cívicas ou de um dever de solidariedade social. COUR EUROPÉENNE DES DROITS DE L'HOMME. Affaire Van der Mussele c/ Belgique, Requête n. 8919/80. Arrêt, Strasbourg, 23 novembre 1983, §38. Disponível em: https://hudoc.echr.coe.int/fre. Acesso em: 30 mar. 2017; COUR EUROPÉENNE DES DROITS DE L'HOMME. Affaire Karlheinz Schmidt c/ Allemagne, Requête n. 13580/88. Arrêt, Strasbourg, 18 juillet 1994, §23. Disponível em: https://hudoc.echr.coe.int/fre. Acesso em: 30 mar. 2017.

${ }^{18}$ Artigo $2^{\circ}$ da Convenção contra a tortura e tratamentos ou penas cruéis, desumanos ou degradantes de 10 de dezembro de 1984.

${ }^{19}$ COUR EUROPÉENNE DES DROITS DE L'HOMME. Affaire Slimani c. France. Requête n. 57671/00. Arrêt du 27 juillet 2004. Disponível em: https://hudoc.echr.coe.int/fre. Acesso em: 31 mar. 2017; COUR EUROPÉENNE DES DROITS DE L'HOMME. Affaire Riad et Idiab c. Belgique. Requêtes n. 29787/03 et 29810/03. Arrêt du 24 janvier 2008. Disponível em: https://hudoc. echr.coe.int/fre. Acesso em: 31 mar. 2017; COUR EUROPÉENNE DES DROITS DE L'HOMME. Affaire Mubilanzila Mayeka et kaniki mitunga c. Belgique. Requête n. 13178/03. Arrêt du 12 octobre 2006. Disponível em: https://hudoc.echr.coe.int/fre. Acesso em: 31 mar. 2017; COUR EUROPÉENNE DES DROITS DE L'HOMME. Affaire Popov c. France. Requêtes n. 39472/07 et 39474/07. Arrêt du 19 janvier 2012. Disponível em: https://hudoc.echr.coe.int/fre. Acesso em: 31 mar. 2017; COUR EUROPÉENNE DES DROITS DE L'HOMME. Affaire Placi v. Italy. Requête n. 48754/11. Arrêt du 21 janvier 2014. Disponível em: https://hudoc.echr.coe.int/fre. Acesso em: 31 mar. 2017; COUR EUROPÉENNE DES DROITS DE L'HOMME. Affaire Hurtado c. Suisse. Requête n. 17549/90. Décision du 28/01/1994. Disponível em: https://hudoc.echr.coe.int/fre. Acesso em: 31 mar. 2017; COUR EUROPÉENNE DES DROITS DE L'HOMME. Affaire Levinta c. Moldova. Requête n.17332/03. Arrêt du 16 dÉcembre 2008. Disponível em: https://hudoc.echr.coe.int/fre. Acesso em: 31 mar. 2017.

${ }^{20}$ COUR EUROPÉENNE DES DROITS DE L'HOMME. Affaire Pretty c/ Royame-Uni, Requête n. 2346/02. Arrêt, Strasbourg, 25 avr. 2002, § 50. Disponível em: https://hudoc.echr.coe.int/fre. Acesso em: 3 abr. 2017.
} 
O mesmo espírito de proteção aos direitos humanos parece ter regido a elaboração da Convenção internacional para a proteção de todas as pessoas contra os desaparecimentos forçados de 2006. Trata-se de uma Convenção Internacional de Direitos Humanos, cujo próprio título refere expressamente o objetivo de proteção das pessoas - daí porque não se vislumbra outro caminho senão a adoção da doutrina da dignidade do ser humano como baliza do Direito Internacional dos direitos humanos e de proteção da humanidade em seu conjunto. A Convenção é ao mesmo tempo uma fonte de Direito Penal nascida no Direito Internacional diante de uma grande lacuna existente nos ordenamentos jurídicos domésticos a propósito da incriminação dos desaparecimentos forçados. Ela constitui-se, por isso, na fonte de um movimento descendente que fará com que o crime passe a integrar progressivamente os Direitos Nacionais. ${ }^{21}$ Além disso, é fruto de um esforço de codificação conjugado das Nações Unidas e da Organização dos Estados Americanos.

Em 1978 a ONU já manifestava a sua preocupação com o desaparecimento de pessoas em todas as regiões do mundo e dos excessos cometidos pelas autoridades supostamente encarregadas da proteção dessas pessoas, bem como de sua consciência acerca do risco que tais práticas representam para a vida, a liberdade e a segurança das pessoas e da angústia e tristeza causadas aos familiares das pessoas desaparecidas. ${ }^{22}$

Impende assinalar o papel da Organização dos Estados Americanos na construção da noção de proibição absoluta dos desaparecimentos forçados, porquanto fora por meio do sistema regional de proteção interamericano que surgira, em 1994, a primeira Convenção sobre o desaparecimento forçado de pessoas, prevendo expressamente o crime de desaparecimento forçado.

Mais do que isso, a Convenção constitui-se em fonte de obrigações positivas aos Estados relativamente ao dever de incriminação: ela promove ao mesmo tempo esse mencionado movimento descendente do Direito regional em direção aos respectivos Direitos domésticos, que passaram a integrá-los progressivamente, além de um movimento ascendente que inspirou a elaboração de uma mesma convenção em âmbito internacional.

Suas origens remontam à Resolução 666 (XIII - 0/83) da Organização dos Estados Americanos, erigida sobre a afirmação de que a prática do desaparecimento forçado de pessoas na América é uma afronta à consciência do hemisfério e constitui um crime contra a humanidade, concepção que irá se sedimentar na jurisprudência da Corte Interamericana de Direitos

\footnotetext{
${ }^{21}$ MARTIN-CHENUT, Kathia. Le renforcement des obligations positives de nature penale dans la jurisprudence interamericaine: l'exemple des graves violations des droits de l'homme commises pendant les dictatures des pays du Cone-Sud. Revue de Science Criminelle et de Droit Pénal Comparé, n. 3, Jui-Sep. 2012, p. 705-725.

22 NATIONS UNIES. Assemblée générale. Resolutions adoptees par l'Assemblee Generale au cours de la trente-troisieme session. Résolution 33/173: Personnes disparues. New York, 20 décembre 1978. Disponível em: http://www.un.org/french/ documents/view_doc.asp?symbol=A/RES/33/173\&Lang=F. Acesso em: 4 abr. 2017.
} 


\section{Humanos e}

Democracia

Humanos, que em diversas oportunidades irá se utilizar de conceitos de Direito Internacional Penal, qualificando a prática de desaparecimento forçado como sendo uma espécie de crime contra a humanidade. ${ }^{23}$

Essa adoção simboliza o quanto no âmbito dos sistemas regionais de proteção se produz um movimento convergente, ora impulsionando a criação de convenções internacionais, alçando-as de um nível regional para um nível universal - caso da Convenção Americana sobre o desaparecimento forçado de pessoas - ora confirmando o sistema normativo previamente criado pelas Nações Unidas.

Nesse sentido, os três principais sistemas regionais de proteção, europeu, americano e africano, ocupam-se dessa mesma construção normativa.

O sistema europeu de proteção dos direitos humanos estabelecido pelo Conselho da Europa tem na Convenção Europeia de Direitos Humanos o seu principal instrumento normativo garantidor de direitos, trazendo a proteção tanto de direitos de natureza absoluta quanto de natureza relativa.

Detendo-se em direitos que se entende serem impassíveis de relativização, verifica-se que a Convenção consagra em seu artigo 10 o direito à não discriminação, elevando-o a um princípio geral baseado na igual dignidade de todos os seres humanos; seu artigo 3ㅇ sedimenta o porte de proibição absoluta à tortura, na medida em que declara ser insuscetível de restrições e derrogações, ${ }^{24}$ igualmente o faz no seu artigo 4 을 em que proíbe a escravatura (e não o trabalho forçado).

Por sua vez, o sistema interamericano de proteção dos direitos humanos foi estabelecido pela Organização dos Estados Americanos, cujos principais instrumentos são a Carta da OEA, a Declaração Americana dos Direitos e Deveres do Homem, ambas adotadas em 1948, e a Convenção Americana de Direitos Humanos, ou Pacto de San José, adotada em 1969. ${ }^{25}$

A Declaração Americana dos Direitos e Deveres do Homem deu origem posteriormente, em 1959, à criação da Comissão Interamericana de Direitos Humanos, órgão que garante a força obrigatória da Declaração, uma vez que competente por velar pela prática ao respeito e promoção dos direitos e garantias nela previstos.

Da mesma forma, a Convenção Americana contém um rol de direitos absolutos, como é o caso do seu artigo 5ㅇ, que proíbe toda forma de tortura, penas ou tratamentos cruéis ou degradantes, relacionando a proibição diretamente com o direito à integridade física e mencionando expressamente o dever de respeito à dignidade do ser humano. A escravidão é

\footnotetext{
${ }^{23}$ CORTE INTERAMERICANA DE DERECHOS HUMANOS. Caso Velásquez Rodríguez Vs. Honduras. San José, Costa Rica: Sentencia (Fondo), 29 de julio de 1988. Disponível em: http://www.corteidh.or.cr/docs/casos/articulos/seriec_04 esp.pdf. Acesso em: 4 abr. 2017; CORTE INTERAMERICANA DE DERECHOS HUMANOS. Caso Goiburú y otros Vs. Paraguay. San José, Costa Rica: Sentencia (Fondo, Reparaciones y Costas), 22 de septiembre de 2006. Disponível em: http://www.corteidh.or.cr/ docs/casos/articulos/seriec_153_esp.pdf. Acesso em: 4 abr. 2017.

${ }^{24}$ SUDRE, Frédéric. Droit européen et international des droits de l'homme. 13e édition refondue. Paris : Presses universitaires de France, 2016, p. 479.

${ }^{25}$ GUERRA, Sidney. O sistema interamericano de direitos humanos e o controle de convencionalidade. São Paulo: Atlas, 2013.
} 
igualmente erigida ao nível de proibição absoluta em seu artigo 6‥ Diferentemente da Convenção Europeia, a Convenção Americana prevê expressamente a proteção da honra e o reconhecimento da dignidade da pessoa humana, sem qualquer exceção. ${ }^{26}$

O sistema africano de proteção dos direitos humanos, criado pela Organização da Unidade Africana, tem na Carta Africana de Direitos Humanos e dos Povos seu principal instrumento de direito convencional em matéria de proteção e promoção dos direitos humanos em âmbito regional, proclamando direitos tanto de natureza individual quanto coletiva, sendo igualmente fonte de obrigações positivas aos Estados na medida em que estabelece o dever de adoção de medidas legislativas a fim de tornar efetivas as prerrogativas enunciadas. ${ }^{27}$

A Carta faz menção expressa à dignidade como objetivo essencial da realização das aspirações dos povos africanos e à necessidade de proteção internacional dos direitos fundamentais do ser humano, ${ }^{28}$ trazendo o direito à igualdade perante a lei como direito absoluto, o qual pode ser interpretado como um direito à não discriminação, ${ }^{29} 0$ direito à vida e à integridade física, ${ }^{30}$ além do direito à dignidade e à proibição da escravatura, do tráfico de pessoas, da tortura e de tratamentos cruéis, desumanos ou degradantes. ${ }^{31}$

A Carta africana ainda inova ao erigir o que denomina direitos dos povos, proclamando sua igual dignidade, ${ }^{32}$ seu direito à autodeterminação, ${ }^{33}$ seu direito ao respeito à sua identidade e liberdade e o gozo igual do patrimônio comum da humanidade, ${ }^{34}$ além do direito à paz e à segurança, ${ }^{35}$ este último em paralelo à Carta das Nações Unidas.

\footnotetext{
${ }^{26}$ Artigo 1ㅇ-1. 1. Toda pessoa tem direito ao respeito de sua honra e ao reconhecimento de sua dignidade. CONVENÇÃO AMERICANA DE DIREITOS HUMANOS. São José, Costa Rica, 22 de novembro de 1969. Disponível em: https://www.cidh.oas.org/ basicos/portugues/c.convencao_americana.htm. Acesso em: 14 abr. 2016.

${ }^{27}$ Artigo $1^{\circ}$ da Carta Africana dos Direitos Humanos e dos Povos, de 28 de junho de 1981. CARTA AFRICANA DOS DIREITOS HUMANOS E DOS POVOS. Nairobi, 1981. Disponível em: http://www.achpr.org/pt/instruments/achpr/. Acesso em: 15 abr. 2016.

28 Preâmbulo da Carta Africana dos Direitos humanos e dos Povos, de 28 de junho de 1981. CARTA AFRICANA DOS DIREITOS HUMANOS E dos POVOS. Nairobi, 1981. Disponível em: http://www.achpr.org/pt/instruments/achpr/. Acesso em: 15 abr. 2016.

${ }^{29}$ Artigo $3^{\circ}$ da Carta Africana dos Direitos Humanos e dos Povos de 28 de junho de 1981. CARTA AFRICANA DOS DIREITOS HUMANOS E DOS POVOS. Nairobi, 1981. Disponível em: http://www.achpr.org/pt/instruments/achpr/. Acesso em: 15 abr. 2016.

${ }^{30}$ No seu artigo $4^{\circ}$, diferentemente das Convenções europeia e americana, a Carta Africana não faz qualquer espécie de relativização ao direito à vida.

${ }^{31}$ Artigo $5^{\circ}$ da Carta Africana dos Direitos Humanos e dos Povos de 28 de junho de 1981. CARTA AFRICANA DOS DIREITOS HUMANOS E DOS POVOS. Nairobi, 1981. Disponível em: http://www.achpr.org/pt/instruments/achpr/. Acesso em: 15 abr. 2016.

32 Artigo 19 da Carta Africana dos Direitos Humanos e dos Povos de 28 de junho de 1981. CARTA AFRICANA DOS DIREITOS HUMANOS E DOS POVOS. Nairobi, 1981. Disponível em: http://www.achpr.org/pt/instruments/achpr/. Acesso em: 15 abr. 2016.

${ }^{33}$ Artigo 20 da Carta Africana dos Direitos Humanos e dos Povos de 28 de junho de 1981. CARTA AFRICANA DOS DIREITOS HUMANOS E DOS POVOS. Nairobi, 1981. Disponível em: http://www.achpr.org/pt/instruments/achpr/. Acesso em: 15 abr. 2016.

${ }^{34}$ Artigo 22 da Carta Africana dos Direitos Humanos e dos Povos de 28 de junho de 1981. CARTA AFRICANA DOS DIREITOS HUMANOS E DOS POVOS. Nairobi, 1981. Disponível em: http://www.achpr.org/pt/instruments/achpr/. Acesso em: 15 abr. 2016.

${ }^{35}$ Artigo 23 da Carta Africana dos Direitos Humanos e dos Povos de 28 de junho de 1981. CARTA AFRICANA DOS DIREITOS HUMANOS E DOS POVOS. Nairobi, 1981. Disponível em: http://www.achpr.org/pt/instruments/achpr/. Acesso em: 15 abr. 2016.
} 


\section{Humanos e \\ Democracia}

\section{UM NOVO DIREITO INTERNACIONAL?}

A questão que se coloca nesse início de século 21 é se efetivamente a Declaração Universal dos Direitos Humanos e, com ela, todo o sistema de proteção universal dos direitos humanos erigido pelas Nações Unidas, inaugurou uma nova fase do Direito Internacional.

Em princípio, parece que uma primeira mudança que se operou foi efetivamente a colocação do indivíduo na posição de sujeito de direitos e deveres, ao mesmo tempo que o Direito Internacional passou a proteger juridicamente um novo ente, ora denominado humanidade. Essa apreensão da humanidade pelo Direito Internacional pode ter produzido um fenômeno de dupla dimensão: de um lado, a juridicização do conceito de humanidade é transformadora do próprio conceito - de um conceito filosófico e metafísico para um conceito jurídico; de outro lado, o Direito Internacional começa a passar por um processo de humanização propiciado pelo rompimento de algumas de suas bases herdadas do pilar da concepção de soberania do Estado - de um Direito Internacional clássico para um novo Direito Internacional.

As mudanças no conceito de humanidade e da própria concepção do Direito Internacional são resultado de todos esses acontecimentos sociais contemporâneos ao processo, que passaram a exigir a proteção do ser humano na cena internacional e a imposição de limites à razão de Estado. As atrocidades que marcaram o fim do século 19 e a primeira metade do século 20 acabaram por despertar "a consciência jurídica universal para a necessidade de reconceitualizar as próprias bases do ordenamento jurídico internacional". ${ }^{36}$

Esse Direito Internacional nasce de um corpo de princípios e de costumes e transforma-se pouco a pouco em uma ordem jurídica convencional, encontrando um desenvolvimento sem precedentes desencadeado pela Declaração Universal dos Direitos Humanos.

Embora a construção convencional centralizada pelas Nações Unidas não tenha como objeto único a proteção dos direitos humanos, porquanto lhe coube igualmente se ocupar de matérias relativas à paz e à segurança internacionais, assim como a proteção dos direitos humanos não é o objeto único de proteção de alguns sistemas regionais, ${ }^{37}$ junto dela seguiu-se toda uma construção jurisprudencial que deu primazia hierárquica ao que se pode denominar valores humanos intangíveis, dos quais decorrem direitos igualmente universais e absolutos.

Em todo o edifício erguido pela jurisprudência em matéria de interpretação e aplicação do direito internacional dos direitos humanos existe certa convergência de entendimento e mesmo uma influência recíproca de uma Corte sobre outra, mostrando-se não raro encontrar o cruzamento de decisões que podem ser compreendidas como um verdadeiro diálogo entre as Cortes, tanto entre as Cortes de Direitos Humanos entre si quanto destas com as Cortes Internacionais Penais, bem como com as Cortes Constitucionais.

\footnotetext{
${ }_{36}$ CANÇADO TRINDADE, Antônio Augusto. A humanização do direito internacional. Belo Horizonte: Del Rey, 2006. p. 111.

${ }^{37}$ É o caso, por exemplo, do sistema comunitário que se ocupa largamente da elaboração de normas de proteção do mercado comum.
} 
Toda essa construção jurisprudencial em matéria de direitos humanos se desenvolve em duas vertentes principais que se entrecruzam, encontrando-se de um lado o sistema universal de proteção coordenado pelas Nações Unidas e, de outro, os sistemas regionais de proteção nascidos da instituição de organizações internacionais como o Conselho da Europa, ${ }^{38}$ a Organização dos Estados Americanos ${ }^{39}$ e a União Africana. ${ }^{40}$

A construção jurisprudencial baseada no sistema universal de proteção das Nações Unidas encontra seu pilar na Corte Internacional de Justiça, cuja jurisdição contenciosa pode ser exercida sobre os Estados em três diferentes hipóteses: por aceitação dos Estados envolvidos no caso da existência de uma disputa específica em matéria de Direito Internacional; por previsão de um tratado internacional que subentenda a jurisdição da Corte como competente para a solução do litígio (como é o caso da Convenção Sobre a Prevenção e a Punição do Crime de Genocídio); ou ainda por aplicação da cláusula opcional, em que os Estados emitem uma declaração unilateral aceitando a jurisdição da Corte, sendo aplicável a todos os Estados que emitem tal declaração, sendo por isso denominada cláusula de reciprocidade.

Consolidada a jurisdição da Corte, sua decisão possui por consequência a criação de obrigação aos Estados em observá-la, somente cabendo a possibilidade de ser revista a decisão nos casos de descoberta de fato novo decisivo e que na época da decisão era desconhecido, conforme dispõem os artigos 59 a 61 do seu estatuto. ${ }^{41}$

Em matéria de proteção dos valores da humanidade, foram diversas as ocasiões em que a Corte Internacional de Justiça foi instada a se manifestar. Importa especialmente o seu entendimento em matéria de jus cogens e das obrigações dos Estados decorrentes do Direito Internacional, bem como as mudanças de entendimento ocorridas ao longo do tempo, notadamente quanto à natureza do Direito Internacional. Nesse último aspecto parece ter havido um avanço que parte de uma concepção voluntarista do Direito Internacional e deságua em uma visão teleológica voltada à finalidade protetiva. ${ }^{42}$

A jurisprudência da Corte Internacional de Justiça servirá de base para a delimitação do conceito de obrigações erga omnes que alcançam toda a comunidade internacional. Estas diferenciam-se das obrigações decorrentes dos tratados internacionais que têm como objeto

\footnotetext{
38 O Conselho da Europa foi instituído pelo Tratado de Londres de 5 de maio de 1949 e tem como principal base normativa a Convenção Europeia de Direitos Humanos, de 4 de novembro de 1950.

39 Criada pela Carta da Organização dos Estados Americanos em 1941, tendo como texto protetor dos direitos humanos a Convenção Americana de Direitos Humanos, de 22 de novembro de 1969.

40 Criada em 2002 em aplicação à Declaração de Syrte de 9 de setembro de 1999 (sucessora da Organização da Unidade Africana, criada em 25 de maio de 1963), cujo instrumento protetivo de direitos humanos é a Carta Africana dos Direitos Humanos e dos Povos, de 21 de outubro de 1986.

${ }^{41}$ Article 59. La décision de la Cour n'est obligatoire que pour les parties en litige et dans le cas qui a été décidé. Article 60. L'arrêt est définitif et sans recours. En cas de contestation sur le sens et la portée de l'arrêt, il appartient à la Cour de I'interpréter, à la demande de toute partie. Article 61. La révision de l'arrêt ne peut être éventuellement demandée à la Cour qu'en raison de la découverte d'un fait de nature à exercer une influence décisive et qui, avant le prononcé de l'arrêt, était inconnu de la Cour et de la partie qui demande la révision, sans qu'il y ait, de sa part, faute à l'ignorer. La procédure de révision s'ouvre par un arrêt de la Cour constatant expressément l'existence du fait nouveau, lui reconnaissant les caractères qui donnent ouverture à la révision, et déclarant de ce chef la demande recevable. La Cour peut subordonner l'ouverture de la procédure en révision à l'exécution préalable de l'arrêt. La demande en révision devra être formée au plus tard dans le délai de six mois après la découverte du fait nouveau. Aucune demande de révision ne pourra être formée après l'expiration d'un délai de dix ans à dater de l'arrêt. COUR INTERNATIONALE DE JUSTICE. Statut de la Cour International de Justice. Disponível em: http://www.un.org/fr/documents/icjstatute/pdf/icjstatute.pdf. Acesso em: 15 maio 2016.

${ }^{42}$ GUERRA, Sidney. Curso de direito internacional público. 11. ed. São Paulo: Saraiva, 2017.
} 


\section{Humanos e \\ Democracia}

a criação de obrigações limitadas aos Estados signatários. Nesse sentido, à Corte caberá fazer a separação entre o que são princípios de Direito Internacional com aplicação obrigatória, porquanto decorrentes do jus cogens, daqueles que não o são. Quando por ocasião do julgamento do caso Barcelona Traction, Light and Power Company entre Bélgica e Espanha, ${ }^{43}$ a Corte faz a distinção entre as obrigações dos Estados em relação à comunidade internacional em seu conjunto e aquelas que nascem aos Estados no quadro da proteção diplomática.

Em relação às obrigações decorrentes das normas de jus cogens, de alcance erga omnes, a decisão da Corte cita os atos de agressão, o genocídio e as regras concernentes aos direitos fundamentais da pessoa humana. Tais normas compreendem a proteção contra a escravidão e a discriminação racial, as quais estariam integradas a um Direito Internacional que ela caracteriza como sendo de caráter universal ou quase universal. Declara, assim, o jus cogens, ou peremptory rules, como fonte autônoma de direitos, que vão mais além do mero direito convencional, haja vista que se tratam de normas internacionais de vital importância para toda a comunidade internacional.

Essa jurisprudência servirá de parâmetro para as jurisdições internacionais penais, especialmente no que se refere à inclusão da proibição da tortura, dos desaparecimentos forçados e do genocídio como normas decorrentes do jus cogens, de natureza absoluta e, portanto, impassíveis de relativização pelos Estados nacionais.

A substância da Convenção para a prevenção e repressão do crime de genocídio teve seu conteúdo ampliado pela jurisprudência da Corte Internacional de Justiça, inicialmente pelo Parecer Consultivo de 28 de maio de 1951 (reservas à convenção do genocídio), ${ }^{44}$ no qual o direito dos tratados foi analisado com profundidade, especialmente naquilo que diz respeito à possibilidade de os Estados fazerem reservas ao texto de convenções internacionais multilaterais.

A propósito, entendeu a Corte que o direito de fazer reservas não pode comprometer os fins superiores da Convenção, oportunidade em que afirma que os princípios de base da Convenção são aqueles reconhecidos pelas nações civilizadas como obrigando os Estados, mesmo aqueles que se encontram fora do elo convencional. ${ }^{45}$

Reconheceu a Corte como princípio que toda convenção multilateral é fruto de um acordo livremente estipulado sobre cláusulas e que, em consequência, não cabe aos contratantes destruir ou comprometer, por meio de decisões unilaterais ou por acordos particulares, aqui-

${ }^{43}$ COUR INTERNATIONALE DE JUSTICE. Affaire de la Barcelona Traction, Light and Power Company, Limited. (Belgique c. Espagne). Recueil des Arrêts, avis consultatifs et ordonnances. Deuxième phase. Arrêt du 5 février 1970. §§ 33-34. Disponível em: http://www.icj-cij.org/files/case-related/50/050-19700205-JUD-01-00-FR.pdf. Acesso em: 20 abr. 2017.

${ }^{44}$ Nesse parecer consultivo, a Corte Internacional de Justiça respondeu precipuamente à seguinte indagação: «L'Etat qui a formulé la réserve peut-il être considéré comme partie à la Convention aussi longtemps qu'il maintient sa réserve si une ou plusieurs parties à la Convention font une objection à cette réserve, les autres parties n'en faisant pas ?", ou seja, a questão a responder seria a de saber se o Estado contratante que formulou uma reserva pode, enquanto a mantiver, ser considerado parte signatária da Convenção, se os demais Estados não reconheceram essa reserva. COUR INTERNATIONALE DE JUSTICE. Avis Consultatif du 28 Mai 1951. Réserves à la Convention pour la Prévention et la Répression du Crime de Génocide. Layde : Société D’Éditions A. W. Sijhoff, 1951. Disponível em: http://www.icj-cij.org/files/case-related/12/ 012-19510528-ADV-01-00-FR.pdf.

${ }^{45}$ COUR INTERNATIONALE DE JUSTICE. Avis Consultatif du 28 Mai 1951. Réserves à la Convention pour la Prévention et la Répression du Crime de Génocide. Layde : Société D’Éditions A. W. Sijhoff, 1951. Disponível em : http://www.icj-cij.org/files/case-related/12/012-19510528-ADV-01-00-FR.pdf. "Les principes qui sont à la base de la Convention sont des principes reconnus par les nations civilisées comme obligeant les Etats même en dehors de tout lien conventionnel”, p. 12. 
lo que é a finalidade e a razão de ser da Convenção. Nem por isso, no entanto, é defeso às partes fazer reservas, o que irá depender de sua natureza. A Corte, nesse aspecto, relativizou a concepção da absoluta integridade das convenções multilaterais, deixando de considerá-la uma regra de Direito Internacional em função da finalidade de participação do maior número de Estados, sob pena de ofensa aos princípios de moral e de humanidade que regem uma Convenção de Direito das Gentes.

Por isso as reservas, não podendo desfigurar a finalidade de uma convenção multilateral, para o caso da Convenção do Genocídio deve-se ter presente a intenção das Nações Unidas de condenar e reprimir um crime do Direito das Gentes que implica a recusa do direito à existência de determinados grupos humanos inteiros de forma a chocar a consciência humana e a infligir grandes perdas à humanidade. A Corte, assim, reconheceu princípios que se encontram na base da convenção, os quais são reconhecidos pelas nações civilizadas e que obrigam os Estados mesmo fora do elo convencional. Além disso, atribuiu caráter universal tanto à condenação do genocídio quanto à cooperação necessária para liberar a humanidade de um flagelo que adjetivou de odioso.

Quanto aos fins da Convenção, a CIJ ressaltou precipuamente seu caráter humanitário e civilizador, que visa a salvaguardar a existência de grupos humanos e confirmar princípios de moral elementares. Por essa razão, os Estados-parte da Convenção não possuem interesses próprios, ${ }^{46}$ mas apenas um interesse comum, que é o de preservar os fins superiores e a própria razão de ser da Convenção. Esse entendimento demonstra que em determinadas matérias existiria um consenso da comunidade internacional sobre o interesse de proteção, decorrente do caráter essencial de algumas normas para a ordem jurídica internacional ${ }^{47}$ ou dos interesses fundamentais da comunidade internacional. ${ }^{48}$

Posteriormente, por ocasião do julgamento do caso das atividades armadas no território do Congo, a obrigação erga omnes dos Estados no que tange à prevenção e repressão do genocídio foi relembrada pela Corte Internacional de Justiça. ${ }^{49}$

Em matéria intimamente relacionada com o pertencimento de algumas normas ao núcleo de jus cogens, a Corte Internacional de Justiça depara-se com algumas ocasiões de se pronunciar sobre o efeito que essas regras possuem de imporem obrigações aos Estados.

A concepção de supremacia do Direito Internacional naquilo em que protege os seres humanos contra a prática de violações graves, como é a hipótese de prática do crime de genocídio, é igualmente evidenciada na decisão da Corte Internacional de Justiça no caso relativo às atividades armadas no território do Congo, cuja decisão afirma expressamente que os

\footnotetext{
${ }^{46}$ Como ter-se-á oportunidade de discutir mais longamente, discorda-se dessa opinião segundo a qual as obrigações decorrentes de tratados internacionais obrigam apenas os Estados signatários. No nosso entendimento, em relação aos tratados que portam a proteção de um núcleo intangível de valores, as obrigações que dele decorrem são de natureza erga omnes, impondo-se tanto aos Estados-partes quanto aos Estados não signatários, assim como aos indivíduos.

${ }^{47}$ DIACONU, Ion. Contribuition à une étude sur les normes impératives en droit international (jus cogens). Bucarest: Impr. Institut international de Technologie et d'économie Apicole d'Apimondia, 1971. p. 106-107.

48 DANILENKO, Gennady M. Law-Making in the International Community. Dordrecht/Boston/London: Martinus Nijhoff, 1993, p. 234.

49 COUR INTERNATIONALE DE JUSTICE. Affaire de des Activités Armées sur le territoire du Congo (République Démocratique du Congo C. Ouganda). Recueil des arrêts, avis consultatifs et ordonnances. Arrêt du 19 Décembre 2005. Disponível em: http://www.icj-cij.org/files/case-related/116/116-20051219-JUD-01-00-FR.pdf. Acesso em: 23 abr. 2017.
} 


\section{Humanos e \\ Democracia}

princípios de base da Convenção são reconhecidos pelas Nações civilizadas, os quais obrigam os Estados, mesmo na ausência de qualquer elo convencional, e isto em virtude do caráter universal da condenação do genocídio e da cooperação que se faz necessária entre todos os membros da comunidade internacional, especialmente os Estados, a fim de libertar a humanidade de um flagelo tão odioso. A decisão acrescenta que por consequência desse postulado, os direitos e obrigações consagrados pela Convenção são de natureza erga omnes. ${ }^{50}$

Resta evidenciada nesta decisão a ausência de caráter voluntarista do Direito Internacional, naquilo que protege os seres humanos da preservação de seus valores superiores, com vistas a prevenir e a reprimir violações a direitos que possuam esses valores como subjacentes. Ao mencionar que os princípios de base da Convenção obrigam os Estados fora do elo convencional, princípios esses ligados à preservação da humanidade contra uma prática odiosa como o genocídio, a Corte eleva o conteúdo material da convenção ao status de Direito Internacional costumeiro, oponível aos Estados independentemente de sua vontade.

A razão pela qual os princípios contidos em Convenções como a do genocídio obrigam os Estados além de qualquer elo convencional é ainda mais bem explicitada pela CIJ na decisão do caso Bósnia-Herzegovina contra Sérvia e Montenegro, no caso relativo à aplicação da Convenção para a prevenção e a repressão do crime de genocídio.

A decisão afirma que a fim de determinar a natureza das obrigações impostas aos Estados, é preciso analisar os propósitos de uma Convenção, observando-se que no caso da Convenção do Genocídio, o crime por ela previsto se constitui em uma ofensa ao Direito das Gentes, porquanto implica a negação do direito de existência a grupos humanos inteiros, constituindo-se em uma recusa que perturba sobremaneira a consciência humana e inflige perdas à humanidade. Esse postulado teria, portanto, segundo a Corte, duas consequências: a imposição de obrigações aos Estados independentemente de sua anuência, dotados da natureza de engajamentos impassíveis de reservas, e o caráter universal da condenação do genocídio, decorrente da finalidade humana e civilizadora da Convenção. ${ }^{51}$

A Convenção do Genocídio e sua interpretação ampliativa pela Corte Internacional de Justiça será de ainda maior valia para a elaboração dos estatutos das jurisdições penais internacionais e a jurisprudência dessas Cortes irá lembrar, em diversas ocasiões, a gravidade da infração.

\footnotetext{
${ }^{50}$ COUR INTERNATIONALE DE JUSTICE. Affaire de des Activités Armées sur le territoire du Congo (République Démocratique du Congo c/ Rwanda). Nouvelle requête. 2002. Compétence de la Cour et Recevabilité de la Requête. Arrêt du 3 février 2006, § 64. Disponível em: http://www.icj-cij.org/files/case-related/126/126-20060203-JUD-01-00-FR.pdf. Acesso em: 23 abr. 2017.

${ }^{51}$ COUR INTERNATIONALE DE JUSTICE. Affaire relative à l'application de la Convention pour la prévention et la répression du crime de génocide (Bosnie-Herzegovine c/ Serbie et Montenegro). Arrêt du 26 février 2007, §§161-162. Disponível em: http://www.icj-cij.org/files/case-related/91/091-20070226-JUD-01-00-FR.pdf. Acesso em: 24 abr. 2017.
} 
Embora a Corte Internacional de Justiça tenha em alguns momentos oscilado e tomado posições restritivas em relação à amplitude das normas imperativas ${ }^{52}$ e a imposição de obrigações erga omnes relativamente a alguns direitos, ${ }^{53}$ de outro lado posicionamentos arrojados foram decisivos para o avanço do Direito Internacional, especialmente no que se refere à luta contra a impunidade de violações graves e massivas contra a humanidade.

É o caso da decisão proferida no caso Bélgica contra Senegal sobre questões concernentes à obrigação de processar ou de extraditar, tendo como objeto o pedido de que o Senegal extraditasse ou desse início ao procedimento penal contra o ex-ditador Hissène Habré, decisão que se ancora na Convenção internacional contra a tortura.

Apoiando-se no pressuposto de que a proibição da tortura decorre do Direito Internacional costumeiro com caráter de norma imperativa, repousando sobre uma ampla prática internacional sobre a opinião jurídica dos Estados e figurando em numerosos instrumentos internacionais com vocação universal, a Corte decide pela obrigação do Senegal em processar pela prática de tortura, mas retrocedendo no aspecto em que entende que essa obrigação somente nasce a partir da ratificação da Convenção por aquele país. ${ }^{54}$

O dispositivo final da decisão acabou por se constituir em um dos marcos para a repressão de crimes contra a humanidade praticados sob a execução de torturas, pelo fato de que o entendimento da Corte acerca da obrigação de processar (ou de extraditar) foi um dos fatores que desencadearam a criação das Câmaras Extraordinárias do Senegal e que culminou com a condenação do ex-ditador à pena de prisão perpétua. ${ }^{55}$

De todo modo, ainda que tenha havido retrocessos no percurso histórico da sua construção jurisprudencial, a opinião que a Corte Internacional de Justiça faz transparecer de modo geral em matéria de respeito aos direitos mais caros dos seres humanos é uma baliza para o desenvolvimento de um Direito Internacional que aos poucos abandona seus postulados clássicos rumo à construção de um Direito Internacional mais adaptado às necessidades de proteção de valores universais.

Esse perfil protetivo transparece em julgamentos como o do já mencionado caso Nicarágua contra os Estados Unidos da América, ${ }^{56} \mathrm{em}$ um tom que se repete, por exemplo, por ocasião da opinião consultiva sobre a licitude da ameaça ou do emprego de armas nuclea-

\footnotetext{
52 COUR INTERNATIONALE DE JUSTICE. Affaire relative aux Immunités Juridictionnelles de l'État (Allemagne c/ Italie; Grèce intervenant). Arrêt du 3 février 2012. Disponível em: http://www.icj-cij.org/files/case-related/143/143-20120203-JUD-01-00-FR.pdf. Acesso em: 24 abr. 2017.

${ }^{53}$ No caso relativo ao Timor Oriental, a Corte não acolhera o requerimento de julgar a responsabilidade da Austrália como membro das Nações Unidas, sob o argumento de que o direito dos povos de autodeterminação não seria oponível erga omnes. COUR INTERNATIONALE DE JUSTICE. Affaire relative au Timor Oriental. Portugal c/ Australie. Arrêt du 30 Juin 1995, §29. Disponível em: http://www.icj-cij.org/files/case-related/84/084-19950630-JUD-01-00-FR.pdf. Acesso em: 27 abr. 2017.

${ }^{54}$ COUR INTERNATIONALE DE JUSTICE. Questions concernant l'obligation de poursuivre ou d'extrader. Belgique c. Sénégal. Arrêt du 20 juillet 2012, §§ 99-105. Disponível em: http://www.icj-cij.org/files/case-related/144/144-20120720-JUD-0100-FR.pdf. Acesso em: 27 abr. 2017.

${ }^{55}$ CHAMBRE AFRICAINE EXTRAORDINAIRE D’ASSISES. Ministère Public c/ Hissein Habré. Jugement rendu le 30 mai 2016. Disponível em: http://www.forumchambresafricaines.org/docs/JugementCAEd'Assises_Penal\&Civil_.pdf. Acesso em: 28 abr. 2017.

${ }^{56}$ COUR INTERNATIONALE DE JUSTICE. Affaire des activités militaires et paramilitaires au Nicaragua et contre celui-ci (Nicaragua c. Etats-Unis d'Amérique). Arrêt du 27 juin 1986. C.I.J. Recueil 1986, p. 114.
} 


\section{Humanos e \\ Democracia}

res, ${ }^{57}$ bem como da opinião consultiva relativa às consequências jurídicas da edificação de um muro no território palestino, reportando-se a Corte às obrigações mais fundamentais do direito humanitário e ao fato de que considerações elementares de humanidade se impõem a todos os Estados, tenham ou não ratificado os instrumentos convencionais. ${ }^{58}$

Nesses casos, a Corte reiterou que as regras de direito humanitário possuem como finalidade o respeito à pessoa humana e que diante de considerações elementares de humanidade elas se impõem a todos os Estados, criando-Ihes obrigações imperativas e erga omnes, tenham eles ou não ratificado os instrumentos convencionais, uma vez que se constituem em princípios intransigíveis do direito costumeiro. Decisões dessa natureza fazem transparecer uma mudança do eixo de preocupação do Direito Internacional, na medida em que se coloca em um plano secundário os interesses dos Estados e passa-se a ter em seu centro a salvaguarda dos seres humanos e da humanidade em seu conjunto.

As obrigações dos Estados em virtude da violação do Direito Internacional dos direitos humanos foram igualmente demarcadas pela Corte Internacional de Justiça no julgamento do caso das atividades armadas sobre o território do Congo, movido pela República Democrática do Congo contra Uganda. ${ }^{59}$ Entre outros fatos, a Corte apreciou a alegação de violação do Direito Internacional dos direitos humanos e igualmente do Direito Internacional humanitário, sob o argumento de que forças armadas ugandesas teriam cometido violações massivas de direitos humanos no território congolês, de modo a acarretar ao Estado demandado as consequências jurídicas decorrentes da violação de suas obrigações internacionais, compreendendo a obrigação de reparar integralmente os prejuízos causados por um fato internacionalmente ilícito.

A Corte teve a oportunidade de examinar as afirmações do Estado demandante, no sentido de que as forças armadas ugandesas teriam causado perdas de vidas humanas no seio da população civil, cometido atos de tortura e outras formas de tratamento desumano, além da destruição de vilarejos e habitações pertencentes a civis e incitação de conflitos étnicos. A decisão conclui pela caracterização da responsabilidade internacional de Uganda por sua responsabilidade pela violação do Direito Internacional dos direitos humanos e do Direito humanitário. O descumprimento das obrigações internacionais advém, segundo a Corte, da imposição de imenso sofrimento da população congolesa decorrente das atrocidades que foram cometidas durante o conflito. ${ }^{60}$

\footnotetext{
${ }^{57}$ COUR INTERNATIONALE DE JUSTICE. Licéité de la Menace ou de L'emploi D'armes Nucléaires. Avis Consultatif du 8 Juillet 1996, §79. Disponível em: http://www.icj-cij.org/files/case-related/95/095-19960708-ADV-01-00-FR.pdf. Acesso em: 23 abr. 2017.

58 COUR INTERNATIONALE DE JUSTICE. Conséquences Juridiques de L'édification d'un Mur dans Le Territoire Palestinien Occupé. Avis Consultatif du 9 Juillet 2004, §157. Disponível em: http://www.icj-cij.org/files/case-related/131/13120040709-ADV-01-00-FR.pdf. Acesso em: 30 abr. 2017

${ }^{59}$ COUR INTERNATIONALE DE JUSTICE. Affaire des Activités Armées sur le territoire du Congo (République Démocratique du Congo C. Ouganda). Recueil des arrêts, avis consultatifs et ordonnances. Arrêt du 19 Décembre 2005. Disponível em: http://www.icj-cij.org/docket/files/116/10454.pdf. Acesso em: 23 abr. 2017.

${ }^{60}$ COUR INTERNATIONALE DE JUSTICE. Affaire des Activités Armées sur le territoire du Congo (République Démocratique du Congo C. Ouganda). Recueil des arrêts, avis consultatifs et ordonnances. Arrêt du 19 Décembre 2005, §§ 206, 211, 220221. Disponível em: http://www.icj-cij.org/docket/files/116/10454.pdf. Acesso em: 23 abr. 2017.
} 
Em todas essas construções, a Corte Internacional de Justiça aportou contribuições importantes sobre questões como a aplicação dos tratados internacionais, o valor do Direito Internacional costumeiro e dos princípios gerais de Direito Internacional, assim como sobre a responsabilidade internacional do Estado, auxiliando, assim, a precisar a existência e os contornos de certas normas fundamentais da comunidade internacional. ${ }^{61}$

O caráter obrigatório de determinados princípios oriundos do ordenamento internacional e a obrigação dos Estados decorrente de sua inobservância serão igualmente evocados na jurisprudência da Corte Interamericana de Direitos Humanos, especialmente nos votos arrazoados do juiz Antônio Augusto Cançado Trindade.

No caso Blake vs. Guatemala, em que o Estado é condenado pela prática de crime de desaparecimento forçado, o juiz Cançado Trindade refere-se à consagração de obrigações erga omnes de proteção como sendo uma manifestação da emergência de normas imperativas do Direito Internacional, a qual representaria a própria superação da autonomia da vontade do Estado, que não poderia ser evocada diante da existência de normas de jus cogens. Trata-se, segundo o jurista, de uma evolução da consciência jurídica universal em benefício de todos os seres humanos. ${ }^{62}$

Na mesma linha de pensamento, no seu voto arrazoado no caso Barrios Altos c. Peru, violação ao direito à vida, à integridade física e à prática de desaparecimento forçado e, nesta hipótese, abrigados por uma lei de autoanistia, Cançado Trindade refere que tais leis ferem direitos inderrogáveis, universalmente reconhecidos, que recaem no âmbito do jus cogens. Faz ainda referência ao edifício principiológico erguido desde o advento da Cláusula Martens e sua contribuição na construção dos princípios humanitários, a qual deve ser utilizada como fonte de interpretação no sentido de impedir a existência de regras que não sejam criadas em benefício de todo o gênero humano, dado o caráter de jus cogens que a cláusula contém, entendendo, por isso, que leis de autoanistia, por exemplo, nada mais são do que uma afronta inadmissível à consciência jurídica da humanidade. ${ }^{63}$

A referência à prática de crimes contra a humanidade como sendo as violações mais graves a direitos que visam à proteção de valores universais transparece em muitas outras decisões da Corte Interamericana de Direitos Humanos.

\footnotetext{
${ }^{61}$ CARREAU, Dominique; MARRELLA, Fabrizio. Droit international. 11ème édition. Paris: Pédone, 2012. p. 690.

${ }^{62}$ CORTE INTERAMERICANA DE DERECHOS HUMANOS. Caso Blake vs. Guatemala. San José, Costa Rica: Sentencia (Fondo), 24 Enero 1998. Voto razonado del juez A. A. Cançado Trindade. § 28. Disponível em: http://www.corteidh.or.cr/docs/casos/ articulos/seriec_36_esp.pdf. Acesso em: 10 dez. 2017.

63 "[...] en el dominio del Derecho Internacional de los Derechos Humanos, las llamadas 'leyes' de autoamnistía no son verdaderamente leyes: no son nada más que una aberración, una afrenta inadmisible a la conciencia jurídica de la humanidad". CORTE INTERAMERICANA DE DERECHOS HUMANOS. Caso Barrios Altos Vs. Peru. San José, Costa Rica: Sentencia (Fondo), 14 de março de 2001. Voto concurrente del juez A. A. Cançado Trindade. §§ 10-11; §§ 22-29. Disponível em: http://www. corteidh.or.cr/docs/casos/articulos/Seriec_75_esp.pdf. Acesso em: 30 abr. 2017.
} 


\section{Humanos e \\ Democracia}

No caso Goiburú, que versa sobre a prática de desaparecimento forçado no âmbito da Operação Condor, ${ }^{64}$ a Corte lembra, por meio do voto arrazoado de Cançado Trindade, que o ordenamento jurídico internacional deu início gradualmente ao processo de criminalização de graves violações aos direitos humanos e que tais normas alcançaram a mais alta hierarquia na medida em que consagram proibições de jus cogens, no intuito de evitar que ofensas dessa natureza se repitam. Tal processo, impulsionador da evolução do Direito Internacional contemporâneo, vem acompanhado do estabelecimento de uma jurisdição internacional penal que se ampara em um princípio de proteção de valores superiores. Esse processo, segundo o juiz, deve-se à intensificação do clamor de toda a humanidade, por ele denominado consciência jurídica universal, contra as atrocidades que têm vitimizado milhões de seres humanos. ${ }^{65}$

No julgamento do caso Almonacid Arellano, que tem como um dos pontos centrais a invalidade de concessão de anistia em matéria de grave violação de direitos humanos, mais uma vez com ainda maior clareza do teor do voto arrazoado do juiz Cançado Trindade, ressai da decisão da Corte o entendimento de que ofensas que configuram crimes contra a humanidade são regidas por normas proibitivas que pertencem ao domínio do jus cogens e que por isso escapam ao domínio do Direito Nacional a opção de punir ou não punir. ${ }^{66}$

Posicionamentos semelhantes são perceptíveis na construção jurisprudencial da Corte Europeia de Direitos Humanos, a começar pelo tratamento dispensado à prática da tortura, consagrada pela Corte como proibição absoluta.

No paradigmático julgamento do caso Soering contra Reino-Unido, marco da construção jurisprudencial em matéria de proibição de extradição em caso de aplicação da pena de morte, a CEDH classifica a proibição da tortura e de tratamentos desumanos ou degradantes como sendo uma proibição absoluta e decide pela impossibilidade de extraditar, por mais odioso que tenha sido o crime praticado, tendo em vista a possibilidade de que o extraditado seja submetido à pena de morte (ou à tortura, em outros casos) - compreendida pela Corte como sendo um tratamento desumano ou degradante. ${ }^{67}$

\footnotetext{
${ }^{64}$ A Operação Condor foi uma aliança firmada entre as ditaduras militares do Chile, Argentina, Uruguai, Paraguai, Bolívia e Brasil, durante as décadas de 70 e 80 , com vistas a desarticular movimentos de oposição aos regimes. A operação ocorria por meio da perseguição dos opositores políticos, consubstanciadas essencialmente em práticas de torturas, desaparecimentos forçados e homicídios. Sobre o tema, ver: DINGES, John. The Condor Years: How Pinochet and his allies brought terrorism to three continents. New York: The New Press, 2004.

${ }^{65}$ CORTE INTERAMERICANA DE DERECHOS HUMANOS. Caso Goiburú y otros Vs. Paraguay. San José, Costa Rica: Sentencia (Fondo, Reparaciones y Costas), 22 de septiembre de 2006. Voto razonado del Juez A. A. Cançado Trindade, §§6-8. Disponível em: http://www.corteidh.or.cr/docs/casos/articulos/seriec_153_esp.pdf. Acesso em: 4 abr. 2017.

${ }^{66}$ CORTE INTERAMERICANA DE DERECHOS HUMANOS. Caso Almonacid Arellano y otros Vs. Chile. San José, Costa Rica: Sentencia 2006 (Excepciones Preliminares, Fondo, Reparaciones y Costas), 26 de septiembre de. Voto razonado del Juez A. A. Cançado Trindade, §§22-23. Disponível em: http://www.corteidh.or.cr/docs/casos/articulos/seriec_154_esp.pdf. Acesso em: 2 maio 2017.

${ }^{67}$ COUR EUROPÉENNE DES DROITS DE L'HOMME. Affaire Soering c/ Royaume-Uni. Requête n¹4038/88. Jugement rendu le 07 juillet 1989, § 88. Disponível em: https://hudoc.echr.coe.int/eng\#\{«itemid»:[«001-62176»]\}. Acesso em: 3 maio 2017.
} 
Esse posicionamento do juiz europeu que considera que em qualquer circunstância a execução da pena de morte se constitui em tratamento desumano ou degradante tornar-se-á jurisprudência sedimentada, em relação à qual a Corte não irá retroceder. Tal posição representa um avanço quanto aos demais sistemas regionais de proteção, haja vista a inadmissibilidade da pena de morte em todos os países membros do Conselho da Europa. ${ }^{68}$

A Corte Europeia de Direitos Humanos, por meio da sua construção jurisprudencial, concebe um alargamento do conceito de tortura e a qualifica não somente como o fato de alguém sofrer violências físicas, mas também por ser submetido à ausência de cuidados mé$\operatorname{dicos}^{69}$ e traz a dignidade humana como vetor naquilo em que condena o uso da força física contra as pessoas. ${ }^{70}$

Precisamente na análise do conceito de tratamento desumano, a Corte Europeia de Direitos Humanos reporta-se em diversas ocasiões à questão do sofrimento humano e da dignidade humana. No caso Chember contra Rússia, a Corte refere-se expressamente à sanção disciplinar infligida com a finalidade de provocar sofrimento físico e que acarreta a invalidez da vítima; ${ }^{71}$ no caso MSS contra Bélgica, conceitua tratamento desumano e degradante quando humilha o indivíduo, desrespeitando sua dignidade, impondo-lhe sentimentos de medo, angústia ou inferioridade, de forma a quebrar sua resistência moral e física. ${ }^{72}$

Em relação à proteção da dignidade humana, a jurisprudência da CEDH é pródiga em matéria de condições da detenção, entendendo que tais condições, por violarem a dignidade, ferem o disposto no artigo 3o da Convenção Europeia de Direitos Humanos, ${ }^{73}$ afirmando, por exemplo, que a colocação de um detento em uma gaiola de metal durante seu processo público constitui uma afronta à dignidade humana, ${ }^{74}$ bem como consagrando expressamente o direito de todo prisioneiro de restar detido em condições compatíveis com o respeito à sua dignidade. ${ }^{75}$

${ }^{68}$ COUR EUROPÉENNE DES DROITS DE L'HOMME. Affaire Öcalan c. Turquie. Requête n. 46221/99. Arrêt, Strasbourg, 12 mai 2005, § 165. Disponível em: https://hudoc.echr.coe.int/fre. Acesso em: 4 maio 2017; COUR EUROPÉENNE DES DROITS DE L'HOMME. Affaire Al-Saadoon et Mufdhi c. Royaume-Uni. Requête n. 61498/08. Arrêt, Strasbourg, 2 mars $2010, \S 120$. Disponível em: https://hudoc.echr.coe.int/fre. Acesso em: 4 maio 2017.

${ }^{69}$ COUR EUROPÉENNE DES DROITS DE L'HOMME. Affaire Algür c. Turquie. Requête n. 32574/96. Arrêt, Strasbourg, 22 octobre 2002. Disponível em: https://hudoc.echr.coe.int/fre. Acesso em: 4 maio 2017

${ }^{70}$ COUR EUROPÉENNE DES DROITS DE L'HOMME. Affaire Ribitsch c. Autriche. Requête n. 18896/91. Arrêt, Strasbourg, 4 décembre 1995. § 38. Disponível em: https://hudoc.echr.coe.int/fre. Acesso em: 5 maio 2017.

${ }^{71}$ COUR EUROPÉENNE DES DROITS DE L'HOMME. Affaire Chember c. Russie. Requête n. 7188/03. Arrêt, Strasbourg, 3 Juillet 2008. Disponível em: https://hudoc.echr.coe.int/fre. Acesso em: 5 maio 2017.

72 COUR EUROPÉENNE DES DROITS DE L'HOMME. Affaire M.S.S. c. Belgique et Grèce. Requête n. 30696/09. Arrêt, Strasbourg, 21 janvier 2011, § 220. Disponível em: https://hudoc.echr.coe.int/fre. Acesso em: 5 maio 2017.

73 COUR EUROPÉENNE DES DROITS DE L'HOMME. Affaire Kotälla c. Pays-Bas. Requête n. 7994/77. Décision du 6 mai 1978 sur la recevabilité de la requête. Disponível em: https://hudoc.echr.coe.int/fre. Acesso em: 10 ago. 2017.

${ }^{74}$ COUR EUROPÉENNE DES DROITS DE L'HOMME. Affaire Svinarenko et Slyadnev c. Russie. Requêtes n. 32541/08 et 43441/08. Arrêt, Strasbourg, 17 juillet 2014. Disponível em: https://hudoc.echr.coe.int/fre. Acesso em: 9 maio 2017; COUR EUROPÉENNE DES DROITS DE L'HOMME. Affaire Ashot Harutyunyan c. Arménie. Application n. 34334/04. Judgement, Strasbourg, 15 juin 2010. Disponível em: https://hudoc.echr.coe.int/fre. Acesso em: 10 ago. 2017.

75 COUR EUROPÉENNE DES DROITS DE L'HOMME. Affaire Kudla c. Pologne. Requête n. 30210/96. Arrêt, Strasbourg, 26 octobre 2000, § 94. Disponível em: https://hudoc.echr.coe.int/fre. Acesso em: 9 maio 2017. 


\section{Humanos e \\ Democracia}

A mesma relação entre a dignidade humana e a proibição a tratamentos desumanos ou degradantes é feita no que se refere à aplicação da pena de prisão perpétua, em relação à qual a CEDH fizera uma interpretação evolutiva, entendendo que para ser compatível com o artigo 30 da Convenção Europeia de Direitos Humanos, ela deve ser passível de reexame, ${ }^{76}$ sob pena de configuração de restar configurada a violação. Nesse aspecto, a Corte Europeia apresenta igualmente uma evolução relativamente aos demais sistemas regionais, pelo fato de criar uma limitação à imposição da pena de prisão perpétua, demonstrando nitidamente a sua inquietude com a preservação da dignidade humana.

\section{CONSIDERAÇÕES FINAIS}

A adoção de uma série de convenções internacionais de direitos humanos alavancada pela criação das Nações Unidas e a subsequente adoção da Declaração Universal de Direitos Humanos são atos inaugurais de um novo Direito Internacional que coloca o indivíduo como centro de sua proteção. É nesse momento que nasce o Direito Internacional dos Direitos Humanos, ao lado do Direito Internacional Penal, este último criado pelo Estatuto do Tribunal de Nuremberg.

Desse contexto emerge a humanidade como um novo ente, objeto de proteção jurídica, embora com contornos ainda não tão bem definidos. A humanidade torna-se sujeito de direitos, tantos são os textos convencionais que a colocam como objeto de proteção. A humanidade torna-se igualmente vítima, vis a vis da nova figura jurídica do crime contra a humanidade, igualmente aportado pelo Direito Internacional.

O conceito de humanidade começa a ser aprimorado, alicerçado em uma construção casuística, dependente da identificação de condutas que caso a caso passam a ser compreendidas como violadoras de valores universais pertencentes à comunidade humana, trazendo novas reflexões que apontam para a busca de resposta sobre qual deve ser ou quais devem ser o(s) objeto(s) do Direito Internacional.

Essa humanidade-sujeito torna-se igualmente portadora de valores a serem protegidos, mas valores de difícil identificação. Se por um lado o Direito não se descuidou de tipificar caso a caso o que se passou a entender por grave ofensa contra a humanidade, por outro lado negligenciou em estabelecer a substância de uma hierarquia de valores humanos que serviriam como substrato à proteção dos seus direitos.

Essa identificação parece ser possível apenas a partir de uma dissecação acurada do edifício construído pelo conjunto das convenções internacionais e pela construção jurisprudencial em matéria de Direito Internacional dos Direitos Humanos.

A compreensão do sentido de grave violação, a partir da análise das condutas mais graves que já assolaram a humanidade - os crimes contra a humanidade e o crime de genocídio - tornou possível a identificação de dois valores que se entende ocuparem o topo da hierar-

\footnotetext{
${ }^{76}$ COUR EUROPÉENNE DES DROITS DE L'HOMME. Affaire Bodein c. France. Requête n. 40014/10. Arrêt, Strasbourg, 13 novembre 2014. Disponível em: https://hudoc.echr.coe.int/fre\#\{“itemid":[“001-147880"]\}. Acesso em: 15 maio 2017; COUR EUROPÉENNE DES DROITS DE L'HOMME. Affaire Vinter c. Royame-Uni. Requêtes n. 66069/09, 130/10 et 3896/10. Arrêt, Strasbourg, 9 juillet 2013. Disponível em: https://hudoc.echr.coe.int/fre\#\{«itemid»:[«001-122694»]\}. Acesso em: 13 maio 2017; COUR EUROPÉENNE DES DROITS DE L'HOMME. Affaire Murray c. Pays-Bas. Requête n. 10511/10. Arrêt, Strasbourg, 26 avril 2016. Disponível em: https://hudoc.echr.coe.int/fre\#\{“itemid”:[“001-162615”]\}. Acesso em: 17 maio 2017.
} 
quia de um conjunto de normas jurídicas: a proteção da dignidade humana e a interdição do sofrimento. Trata-se de valores que legitimam a existência de direitos de natureza universal e absoluta que fazem parte de um pequeno núcleo intangível: o direito à vida, o direito à integridade física, o direito à liberdade, o direito à liberdade sexual, o direito à não discriminação e o direito à não submissão a tratamentos desumanos, cruéis ou degradantes.

A partir da jurisprudência das Cortes Internacionais e Regionais encarregadas de conferir eficácia à construção convencional, do teor de decisões dessa natureza parece emergir a dignidade humana como um valor subjacente, ocupando, ao lado da interdição do sofrimento, o ápice da hierarquia de valores de cunho universal e absoluto cuja salvaguarda é o fim último de um Direito Internacional voltado para a centralidade do indivíduo.

Especialmente a partir da criação das Nações Unidas e de seu respectivo sistema universal de proteção, tanto normativo quanto jurisdicional, o Direito Internacional dos Direitos Humanos passa a conferir um importante conteúdo valorativo a essa noção de ofensas que afetam o que há de humano no ser humano. A construção normativa catalisada por essa nova estrutura parece fazer emergir a dignidade humana como um valor subjacente aos direitos fundamentais cuja proteção visa a garantir. A dignidade humana aparece como a pedra de toque das normas criadas pelo Direito Internacional dos Direitos Humanos e dessa construção emergem igualmente direitos que não são passíveis de sofrer restrições ou relativizações. A noção de direito humano absoluto nasce dessa composição que tem sua fonte sobretudo nas core conventions, que são pilares desse sistema universal de proteção, que por sua vez inaugura um novo Direito Internacional, não mais ancorado em postulados clássicos fundados no princípio da soberania dos Estados, mas, isto sim, amparado na precípua proteção do indivíduo.

\section{REFERÊNCIAS}

BUERGENTHAL, Thomas. International Human Rights. St. Paul: West Publishing Co., 1988.

CANÇADO TRINDADE, Antônio Augusto. Princípios do direito internacional contemporâneo. 2. ed. Brasília: Fundação Alexandre de Gusmão, 2017.

CARREAU, Dominique; MARRELLA, Fabrizio. Droit international. 11ème édition. Paris: Pédone, 2012.

DELMAS-MARTY, Mireille. Le crime contre l'humanité, les droits de l'homme et l'irréductible humain. Revue de science criminelle et de droit pénal comparé. Paris, n. 3, p. 477-490, juil/sept. 1994.

FROUVILLE, Olivier de. Droit international pénal. Sources. Incriminations. Responsabilité. Paris: Pédone, 2012.

GUERRA, Sidney. Curso de direito internacional público. 11. ed. São Paulo: Saraiva, 2017.

GUERRA, Sidney. Direito internacional dos direitos humanos. 2. ed. São Paulo: Saraiva, 2015.

GUERRA, Sidney. O sistema interamericano de direitos humanos e o controle de convencionalidade. São Paulo: Atlas, 2013.

MARTIN-CHENUT, Kathia. Le renforcement des obligations positives de nature penale dans la jurisprudence interamericaine: l'exemple des graves violations des droits de l'homme commises pendant les dictatures des pays du Cone-Sud. Revue de Science Criminelle et de Droit Pénal Comparé, n. 3, p. 705-725, juil/sept. 2012.

SUDRE, Frédéric. Droit européen et international des droits de l'homme. $13^{\mathrm{e}}$ édition refondue. Paris: Presses Universitaires de France, 2016.

VENTURA-ROBLES, Manuel E. El valor de la Declaración Universal de Derechos Humanos. In: CANÇADO TRINDADE, Antonio Augusto (org.). The modern world of human rights - El mundo moderno de los derechos humanos: Essays in honour of Thomas Buergenthal/Ensayos en Honor de Thomas Buergenthal. San José: Instituto Interamericano de Derechos Humanos, 1996. p. 257-258. 